\title{
Recent Trends (2012-2016) of N, Si, and P Export from the Nemunas River Watershed: Loads, Unbalanced Stoichiometry, and Threats for Downstream Aquatic Ecosystems
}

\author{
Irma Vybernaite-Lubiene ${ }^{1}$, Mindaugas Zilius ${ }^{1}$ (D), Laura Saltyte-Vaisiauske ${ }^{1}$ and \\ Marco Bartoli 1,2,* \\ 1 Marine Research Institute, Klaipeda University, LT-92294 Klaipeda, Lithuania; \\ irma.lubiene@apc.ku.lt (I.V.-L.); mindaugas.zilius@jmtc.ku.lt (M.Z.); laura.saltyte-vaisiauske@ku.lt (L.S.-V.) \\ 2 Department of Chemistry, Life Sciences and Environmental Sustainability, University of Parma, \\ IT-43100 Parma, Italy \\ * Correspondence: marco.bartoli@unipr.it; Tel.: +39-052-190-5048
}

Received: 1 August 2018; Accepted: 28 August 2018; Published: 3 September 2018

\begin{abstract}
The Curonian Lagoon, the largest in Europe, suffers from nuisance cyanobacterial blooms during summer, probably triggered by unbalanced nutrient availability. However, nutrient delivery to this system was never analysed in detail. During 2012-2016, we analysed the monthly discharge, nutrient loads, and ecological stoichiometry at the closing section of the Nemunas River, the main nutrient source to the lagoon. The aim of this study was to investigate seasonal and annual variations of nitrogen $(\mathrm{N})$, silica $(\mathrm{Si})$, and phosphorous $(\mathrm{P})$ with respect to discharge, climatic features, and historical trends. The nutrient loads varied yearly by up to $50 \%$ and their concentrations underwent strong seasonality, with summer $\mathrm{N}$ and $\mathrm{Si}$ limitation. The river discharge $\left(16 \pm 4 \mathrm{~km}^{3} \cdot \mathrm{yr}^{-1}\right)$ was lower than the historical average $\left(21.8 \mathrm{~km}^{3} \cdot \mathrm{yr}^{-1}\right)$. Changes in agricultural practices resulted in similar $\mathrm{N}$ export from the river watershed compared to historical data (1986-2002), while sewage treatment plant improvements led to a $\sim 60 \%$ decrease of $P$ loads. This work contributes new data to the scattered available information on the most important nutrient source to the Curonian Lagoon. Further P reduction is needed to avoid unbalanced dissolved inorganic nitrogen and phosphorus (DIN:DIP 10) ecological stoichiometry in summer, which may stimulate undesired cyanobacterial blooms.
\end{abstract}

Keywords: Nemunas River; nitrogen; silica; phosphorous; loads; ecological stoichiometry

\section{Introduction}

Anthropogenic pressures on ecosystems have led to changes of nutrient genesis, cycling, and transport in watersheds [1-5]. Fertilized agriculture and animal farming alter nitrogen (N) pathways by driving a $\mathrm{N}$ surplus in arable lands, as well as by increasing the risk of $\mathrm{N}$ leaching and water pollution [6-8]. Climate change, which affects snow cover period, precipitation intensity, and timing, may favour soil erosion and increase short-term transport of particulate phosphorus (P) and silica $(\mathrm{Si})$ to coastal areas [9-11]. The varying precipitation patterns may also result in rapid delivery of dissolved nutrients to coastal areas and saturation of their metabolic capacity, resulting in large inputs to the sea $[12,13]$. However, at regional scales, ongoing socio-economic changes may produce larger impacts on biogeochemical cycles than those produced by climate changes [14]. Socio-economic changes may affect entire productive sectors, with variable price of fertilizers and number of livestock affecting $\mathrm{N}$ budgets in watersheds $[15,16]$. The modernization 
of sewage treatment plants and improvement of farm managing practices may reduce point $\mathrm{N}$ and $\mathrm{P}$ inputs to the rivers [8,17]. Socio-economic changes such as increased use of P-free detergents, meat consumption, or shift in population can also alter nutrient dynamics [18]. The construction of dams may result in the net retention of particulate nutrient forms, reducing $\mathrm{P}$ and Si inputs to coastal areas [19]. It is difficult to predict the net cumulative effects of these sometimes opposing processes [20]. In large watersheds, the net effects of socio-economic and climatic changes on nutrient genesis, retention, and transport can be empirically tackled via frequent measurements of discharge and water quality at gauging sections. The monitoring of nutrient loads generated in watersheds, of their short- and long-term temporal trends and of their ecological stoichiometry, is particularly important when watersheds border sensitive areas, such as eutrophic estuaries or closed seas and gulfs [21,22]. In these critical areas, the delivery of unbalanced nutrient loads may favour harmful algal blooms, with positive feedback for organic enrichment and anoxia, and negative impacts for fisheries, recreational activities, local economies, and biodiversity [12,23,24].

In this study, we investigated the monthly loads of $\mathrm{N}, \mathrm{Si}$, and $\mathrm{P}$ exported from the Nemunas River watershed (Belarus and Lithuania) to the coastal area of the Baltic Sea over a 5-year period. The Nemunas River is the main freshwater and nutrient source of the largest European estuary, the Curonian Lagoon, and is among the five major point nutrient source, together with Neva, Oder, Dauguva, and Vistula rivers, to the Baltic Sea. Both the Curonian Lagoon and Baltic Sea are critically sensitive areas, as they suffer from eutrophication, cyanobacterial blooms, and anoxia, as well as loss of biodiversity and fish stocks, which have detrimental effects on the local and macro-regional economies [25-28]. Reversal of eutrophication in these areas can be achieved through a substantial and balanced reduction of nutrient delivery from rivers that drain into agricultural and densely populated watersheds, such as the Nemunas [29,30]. This type of balanced reduction should not produce conspicuous variations of the $\mathrm{N}, \mathrm{Si}$, and $\mathrm{P}$ ecological stoichiometry that would favour harmful algal blooms (i.e., with $\mathrm{N}$ and $\mathrm{Si}$ limitation or P excess, [26,31,32]. Under $\mathrm{N}$-limitation (16 >> DIN:DIP) $\mathrm{N}_{2}$-fixing, harmful cyanobacteria can be favoured and replace other pelagic primary producers [33].

The main aim of the present study was to analyse the variation of the loads of three key macronutrients $(\mathrm{N}, \mathrm{Si}$, and $\mathrm{P})$ and their stoichiometry at the Nemunas River closing section in response to seasonality and river discharge. A second aim was to add a robust (5-year) dataset to previously published investigations on nutrient loads to the Baltic Sea from the Nemunas River (e.g., N loads in the period 2000-2006 [29]; N and P loads in the period 2008-2010 [30]). Long-term monitoring actions are necessary due to the ongoing socio-economic and climatic changes in this geographical area $[15,30]$. It is also important to analyse the impact of policy implementation on water quality and quantify whether measures such as the "European Union Nitrate and Urban Wastewater Directives" are effective at reducing the Nemunas River nutrient loads to the Baltic Sea $[29,34,35]$. Overall, long-term monitoring is also needed because of slow ecosystem response times, e.g., lag times between changes in terrestrial nutrient management and land-water nutrient transfer or riverine loads decrease and within river nutrient transformations processes. Different studies have demonstrated that substantial nutrient reductions (i.e., those related to $\mathrm{N}$ loads) may occur many years after the implementation of initiatives, such as the reduction in fertilizer use, due to the accumulation and slow release of $\mathrm{N}$ from soil $[20,34,36]$. A few investigations carried out in small catchments within the geographical area of the Baltic States have highlighted large variations in agricultural practices and climate and analysed their effect on $\mathrm{N}$ loss [37]. However, to our knowledge, there are no investigations in this geographical area targeting simultaneously the dissolved and particulate forms of $\mathrm{N}, \mathrm{Si}$, and $\mathrm{P}$. The ecological stoichiometry of these three macronutrients, more than single element loads, is an important attribute of nutrient loads exported from a large watershed, as it affects algal communities and may trigger harmful algal blooms in adjacent estuarine and coastal areas $[6,31,38]$. 


\section{Materials and Methods}

\subsection{Study Area}

The Nemunas River is the largest river in Lithuania and has a catchment area of 97,864 $\mathrm{km}^{2}$, of which $46,695 \mathrm{~km}^{2}$ is located in Lithuania, $45,389 \mathrm{~km}^{2}$ is located in Belarus, and the rest is located in Latvia, Poland, and the Kaliningrad area [39] (Figure 1). Cultivated lands and forested areas cover nearly $60 \%$ and $40 \%$ of the Nemunas River basin, respectively [40]. The annual precipitation in the Nemunas River basin varies from 520 to $800 \mathrm{~mm}$ [15]. The river flow of the Nemunas exhibits a strong seasonal pattern, peaking with snowmelt during the flood season in March and April [24]. The Nemunas River empties into the Curonian Lagoon, which discharges to the Baltic Sea through a narrow strait. With a long-term mean flow of $700 \mathrm{~m}^{3} \cdot \mathrm{s}^{-1}$, the Nemunas River is the third largest tributary to the Baltic Sea $[30,41]$. In the present study, the sampling site was situated in the downstream stretch of the Nemunas River, 16 km upstream of the Curonian Lagoon.

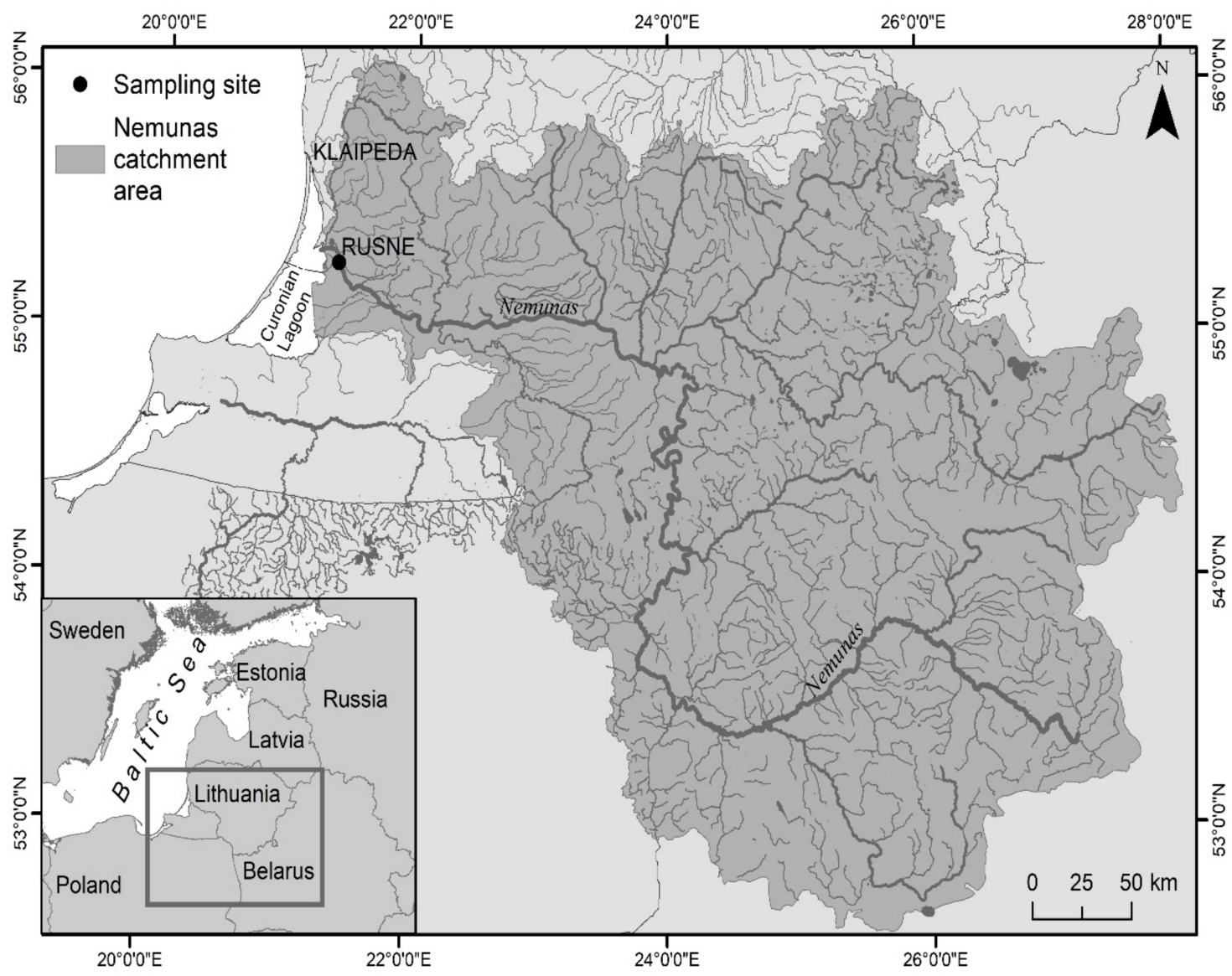

Figure 1. Map of the Nemunas River catchment area (dark grey area), with the water sampling site at the Nemunas River closing station indicated.

\subsection{Sample Collection}

Monthly samples were collected from January 2012 to December 2016. Short-term periods with unusual, high discharge may determine large transport of dissolved and particulate nutrients, that are not considered in routine sampling activities and lead to underestimated annual loads. We therefore intensified our sampling activities during the high discharge periods, generally from January to April. We have missed only a high discharge event, in April 2013. Water samples (2 L) were collected in triplicate, integrating the whole water column with repeated Ruttner bottle sampling at the surface (0.4 $\mathrm{m}$ depth) and bottom layers (3.0 $\mathrm{m}$ depth). Integrated water samples were transferred to opaque 
high density plastic bottles, cooled with ice packs, and transported to the laboratory within two hours for subsequent treatment and analyses.

\subsection{Dissolved Nutrient Analyses}

In the laboratory, water samples $(n=3)$ were filtered (see the next paragraph for the filter specifications) and transferred to $10 \mathrm{~mL}$ glass tubes and $20 \mathrm{~mL}$ glass vials to analyse dissolved $\mathrm{N}$ and $\mathrm{P}$, respectively, as described in Vybernaite-Lubiene et al. [24]. Filtered aliquots for Si measurements were transferred into $12 \mathrm{~mL}$ PE tubes. The dissolved nitrite $\left(\mathrm{NO}_{2}{ }^{-}\right)$, combined nitrite and nitrate $\left(\mathrm{NO}_{\mathrm{x}}{ }^{-}\right)$, dissolved silica (DSi) and inorganic phosphorus (DIP) concentrations of the filtered water samples were measured with a 4-channel continuous flow analyser $\left(\mathrm{San}^{++}\right.$, Skalar) using standard colorimetric methods [42]. $\mathrm{NO}_{3}{ }^{-}$was calculated as the difference between $\mathrm{NO}_{\mathrm{x}}{ }^{-}$and $\mathrm{NO}_{2}{ }^{-}$. Dissolved ammonium $\left(\mathrm{NH}_{4}{ }^{+}\right)$was analysed manually by means of the salicylate-hypochlorite method using nitroprussiate as the catalyst [43].

To calculate the concentrations of the total $\mathrm{N}$ and $\mathrm{P}$ loads, total dissolved nitrogen (TDN) and phosphorus (TDP) were analysed. TDN was determined using the high temperature $\left(680^{\circ} \mathrm{C}\right)$ combustion catalytic oxidation/NDIR method using a Shimadzu TOC V-CPH analyser that included a TN module. TDP was determined after digestion and oxidation of organic $\mathrm{P}$ by alkaline peroxodisulfate acid; afterwards, TDP was quantified spectrophotometrically using the molybdate method [44]. All of the dissolved nutrients were analysed within $12 \mathrm{~h}$, except for TDP, for which the sample was immediately frozen and analysed later, within 3 weeks. The dissolved organic forms of $\mathrm{N}$ and $\mathrm{P}$ (DON and DOP) were calculated by difference.

\subsection{Particulate Nutrient Analysis}

Whatman GF/F glass fiber filters (diameter $0.47 \mathrm{~mm}$, pore size $0.7 \mu \mathrm{m}$ ) were used to analyse particulate nitrogen (PN). The filters were analysed with an Elementar Vario EL Cube (Elementar Analysensysteme $\mathrm{GmbH}$, Hanau, Germany) at the laboratory of the UC Davis Stable Isotope Facility, USA. In parallel, particulate phosphorus (PP) was collected on precombusted Whatman GF/F glass fiber filters (diameter $0.25 \mathrm{~mm}$, pore size $0.7 \mu \mathrm{m}$ ) and later analysed spectrophotometrically using the molybdate method after dissolution into $1 \mathrm{M} \mathrm{HCl}$ for $24 \mathrm{~h}$ [45]. This PP pool includes only the inorganic fraction and underestimates the total particulate $\mathrm{P}$ as the fraction associated to phytoplankton was only partially extracted, analysed, and included in the pool. Whatman Nucleopore polycarbonate filters (diameter $0.47 \mathrm{~mm}$, pore size $0.4 \mu \mathrm{m}$ ) were used for biogenic silica (BSi) analysis. BSi from particulate matter was extracted with $0.2 \mathrm{M} \mathrm{NaOH}$ at $95^{\circ} \mathrm{C}$ in a shaking water bath [46]. After neutralization, the extract was analysed by spectrophotometry using a continuous flow analyser as DSi [42]. This procedure may lead to an overestimation of the BSi pool due to solubilisation of lithogenic Si during the extraction procedure. The sum of dissolved and particulate nutrient concentrations was used for total nitrogen (TN), phosphorus (TP), and silica (TSi) estimates.

\subsection{Load Calculations}

The Lithuanian Hydrometeorological Service provided discharge data from the Nemunas River gauging station. This authority continuously monitors the water levels and discharge and provides daily average values. Our discharge data integrate the Nemunas and three smaller tributaries, Jūra, Šešuvis, and Šešupe (henceforth referred to as the Nemunas River). The monthly loads of dissolved and particulate nutrients were obtained by multiplying the concentrations measured at each sampling date by the mean monthly discharge according to HELCOM [47]. The monthly loads were summed to obtain the annual loads over the 2012-2016 period. The Lithuanian Hydrometeorological Service also provided daily precipitation and air temperature data, which are regularly measured from a grid of 11 stations scattered across the entire Lithuanian portion of the Nemunas River watershed. Data from these stations were combined to calculate the mean monthly precipitation and air temperature values for nearly half of the Nemunas basin. 


\subsection{Statistical Analyses}

The relationships between the dissolved inorganic nutrient concentration and discharge were analysed by linear regression. The assumptions of data normality and homogeneity of variance were verified using Shapiro-Wilk and Cochran's tests, respectively. In the case of heteroscedasticity, data were square-root transformed. The seasonal effects on discharge and the nutrient concentrations were measured by means of a seasonal index that was calculated according to the centred moving averages method. From the entire dataset of discharge and the nutrient concentration, mean values for each parameter were calculated. Monthly observations were then compared to the corresponding expected values under the hypothesis of no seasonal variation. The seasonal index was based on a mean of 1 , and the degree of seasonality was measured by means of variations from this baseline. If a certain month's index value was greater than 1, the parameter was considered to have increased due to a seasonal influence, while if it was less than 1, it the parameter was considered to have decreased due to a seasonal influence. The non-parametric Mann-Kendall test was employed to detect monotonic trends in a series of discharge and nutrient concentration data. The null hypothesis, $\mathrm{H} 0$, is that the data came from a population with independent realizations and were identically distributed. The alternative hypothesis, HA, is that the data followed a monotonic trend (positive or negative). The Seasonal-Mann-Kendall (SMK) trend test was used to test the monotonic trends in a time series with seasonal variation. Hirsch [48] developed this type of test by computing the Kendall score separately for each month. The partial Mann-Kendall (PMK) trend test was used to examine the impact of incorporating information of covariates into the SMK test to determine the trends of serially correlated data collected over several seasons, as suggested by Libiseller and Grimvall [49]. Statistical significance for all analyses was set at $p<0.05$.

\section{Results}

\subsection{Riverine Discharge}

The discharge from the Nemunas River displayed seasonal and interannual variability, with higher flows generally measured during colder months and lower flows measured during warmer months (Figure 2). The highest monthly discharge was measured in April $2013\left(2200 \mathrm{~m}^{3} \cdot \mathrm{s}^{-1}\right)$, and the lowest monthly discharge was measured from August-September $2015\left(<200 \mathrm{~m}^{3} \cdot \mathrm{s}^{-1}\right)$. The total annual discharge from the Nemunas River differed by $34 \%$ during the 5 -year period $\left(2013=19.9 \mathrm{~km}^{3} \cdot \mathrm{yr}^{-1}\right.$, $\left.2015=13.1 \mathrm{~km}^{3} \cdot \mathrm{yr}^{-1}\right)$. Most of the interannual difference was due to the peak flow measured from April-May 2013 and the exceptionally low discharge measured from August-September of 2015. The annual average discharge was $16.4 \mathrm{~km}^{3} \cdot \mathrm{yr}^{-1}\left(518.3 \mathrm{~m}^{3} \cdot \mathrm{s}^{-1}\right)$. During 2012-2016 period, annual discharge was nearly $26 \%$ below historical records $\left(700 \mathrm{~m}^{3} \cdot \mathrm{s}^{-1}\right.$, [41]).

The monthly discharge generally peaked during spring, coinciding with the lowest precipitation levels, and reached a minimum during summer, coinciding with the highest precipitation levels and air temperatures (Figure 2). The single largest flow event, recorded in the spring of 2013, overlapped with a sudden increase in the average air temperature. From March to April 2013, the air temperature increased by $9.4^{\circ} \mathrm{C}$, from -4.1 to $+5.3^{\circ} \mathrm{C}$ (Figure 2). The total annual precipitation and discharge during the study period were linearly correlated, with 2013 being the only exception, likely due to a single, high-flow event following a short-term climatic anomaly. 

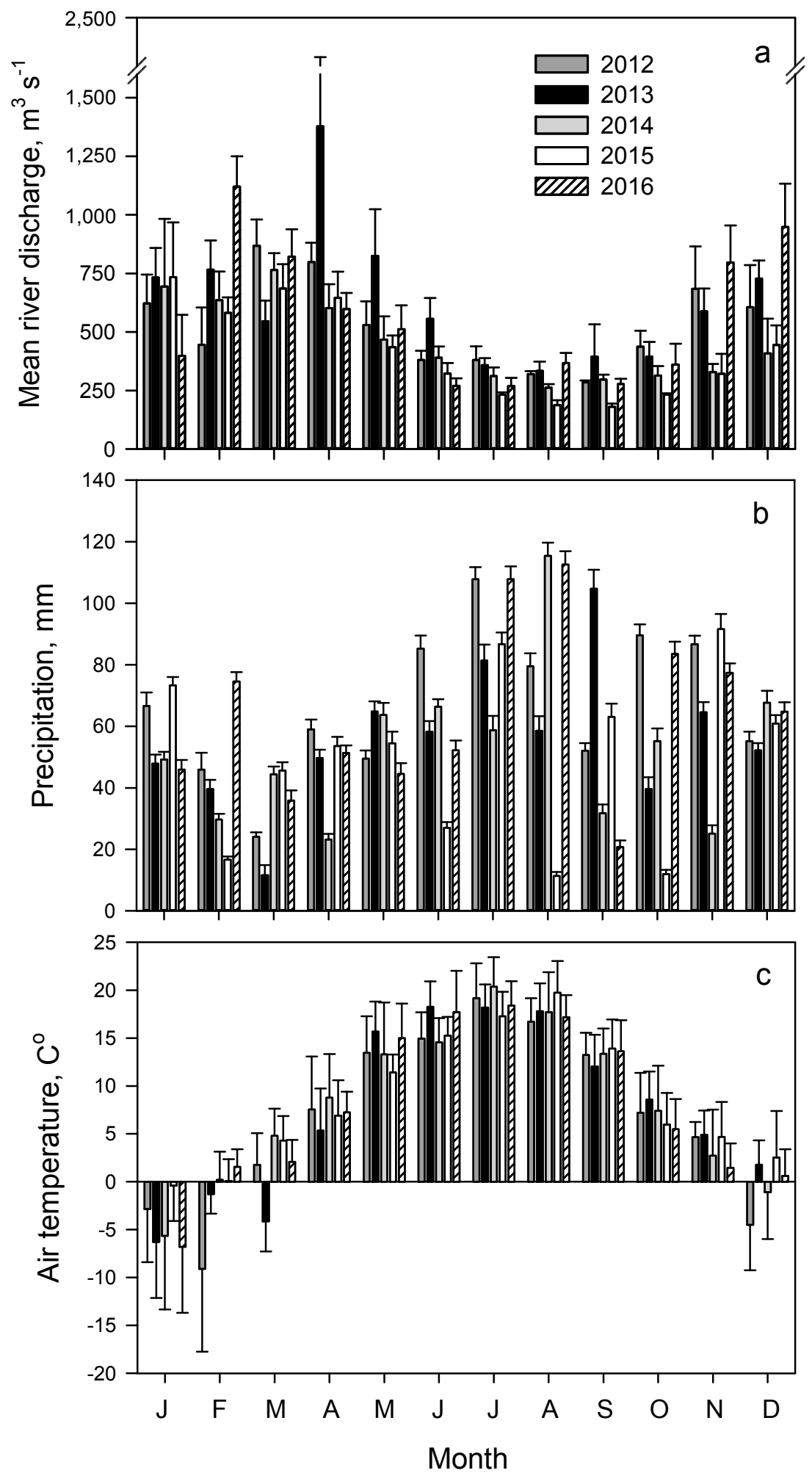

Figure 2. The monthly mean Nemunas River flow (a), precipitation over the Nemunas River watershed (b), and air temperature (c) during 2012-2016.

\subsection{Dissolved Inorganic Nutrient Concentrations}

At the Nemunas River closing section, the concentrations of dissolved inorganic $\mathrm{N}$ displayed strong seasonality, with spring/summer minima and autumn/winter peaks (Figure 3a). The seasonal 
ranges in concentrations of different inorganic forms differed by up to two orders of magnitude (e.g., $\mathrm{NH}_{4}{ }^{+}$varied from $<2$ to $12 \mu \mathrm{M}$, while $\mathrm{NO}_{3}{ }^{-}$varied from $<1$ to $327 \mu \mathrm{M}$ ). $\mathrm{NO}_{3}{ }^{-}$was always the dominant fraction of DIN, while $\mathrm{NH}_{4}{ }^{+}$and $\mathrm{NO}_{2}{ }^{-}$contributed a smaller proportion. The highest mean $\mathrm{NO}_{3}{ }^{-}$concentration $(324 \pm 2 \mu \mathrm{M})$ was measured in November 2016. The $\mathrm{NO}_{2}{ }^{-}$concentrations were always low $\left(<2 \mu \mathrm{M}\right.$, data not shown and were combined with $\mathrm{NO}_{3}{ }^{-}$data).
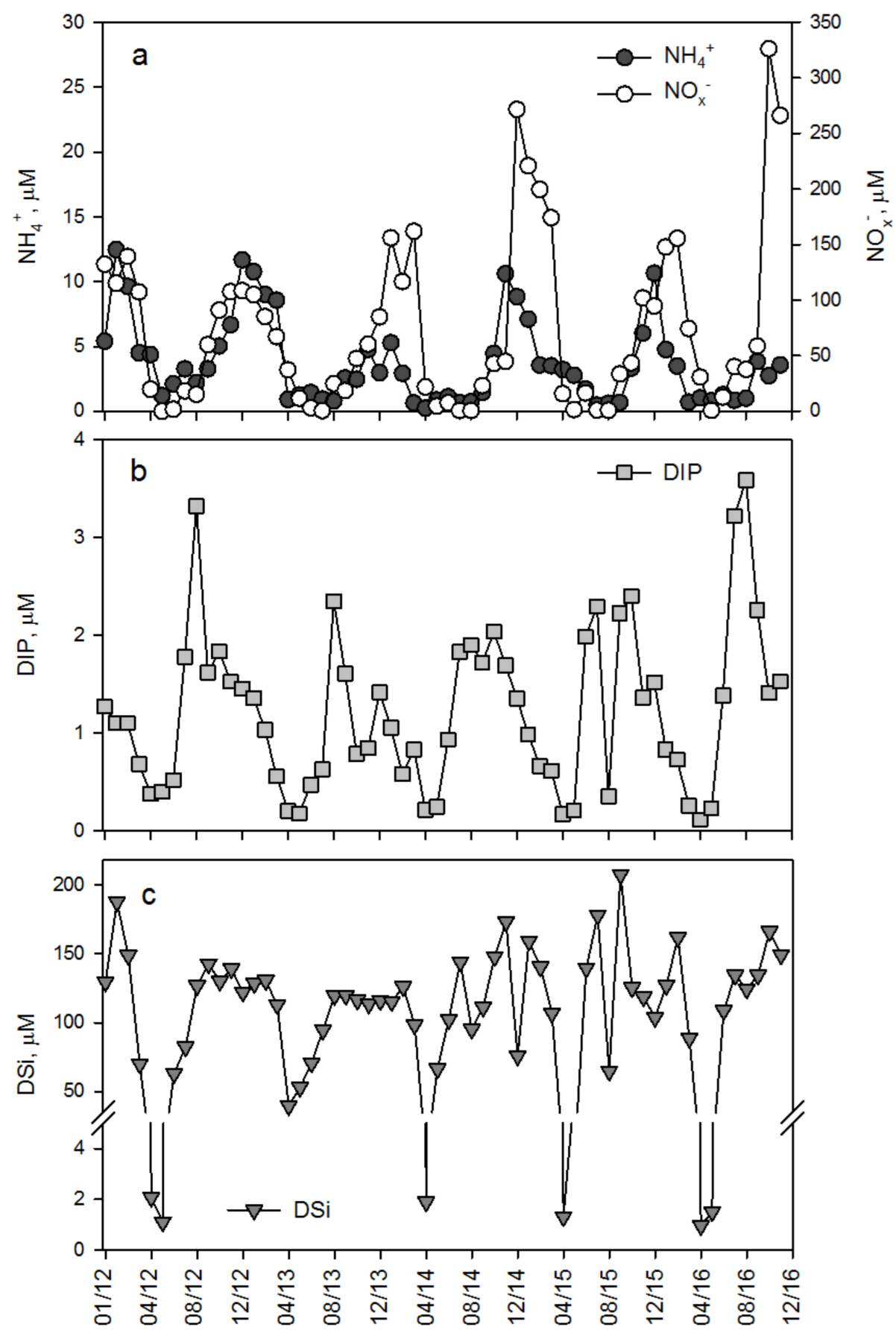

Figure 3. Monthly concentrations of dissolved inorganic nitrogen (a), phosphorus (b), and silica (c) at the Nemunas River gauging station (Rusne station) during the 2012-2016 period.

The concentrations of DIP showed both seasonal and interannual variations (Figure 3b). In colder months, the DIP concentrations were generally in the range of $0.5-1.5 \mu \mathrm{M}$, while they were more variable during other periods. At the beginning of summer, DIP was always depleted, 
with concentrations close to the detection limit of our methods $(0.2 \mu \mathrm{M})$. Later, towards the middle of autumn, its concentration gradually increased to $1.5-2 \mu \mathrm{M}$, with peaks of up to $3.5 \mu \mathrm{M}$ (measured in September 2012 and 2016), but a steep drop in concentration was measured in September 2015.

The concentrations of DSi also followed seasonal patterns, with values between 1 and $200 \mu \mathrm{M}$ (Figure 3c). Low DSi concentrations $(<2 \mu \mathrm{M})$ were generally measured in May, with 2013 being an exception, when the values never dropped below $40 \mu \mathrm{M}$.

After combining all of the data, the concentrations of $\mathrm{NO}_{3}{ }^{-}$were found to be positively correlated with discharge $\left(\left[\mathrm{NO}_{3}{ }^{-}\right]=(0.62 \pm 0.06) \times\right.$ Discharge, $\left.p<0.001\right)$. When data were grouped by year, the slopes of the linear regressions were different, suggesting interannual variability (Table 1 ). In particular, the highest slope was obtained in 2015, coinciding with the lowest annual discharge. By contrast, the lowest slope was measured in 2013, coinciding with the highest river discharge. There was no significant $(p>0.05)$ correlation between the DIP or DSi concentrations and discharge for both pooled data and annual values.

The ratios of dissolved inorganic nutrients varied seasonally, with $\mathrm{N}$ in excess to $\mathrm{P}(80<\mathrm{DIN}$ :DIP) and Si ( $1<$ DIN:DSi) in colder months and N limitation (below Redfield ratio) in warmer months (Figure 4). However, the DIN:DSi ratio was $<1$ during most of the study period, supporting the hypothesis of a prolonged summer $\mathrm{N}$ limitation in downstream aquatic ecosystems. The calculated DIN:DIP ratio suggests unbalanced nutrient stoichiometry ( $\mathrm{N}$ in excess) that lasted for over 8 months per year and a strong $\mathrm{N}$ deficiency in summer, with DIN:DIP $<<16$.

Table 1. The results of linear regressions between nitrate concentrations and the Nemunas River discharge.

\begin{tabular}{cccccc}
\hline Year & Annual Discharge ${\mathbf{~} \mathbf{k m}^{\mathbf{3}} \cdot \mathbf{y r}^{\mathbf{- 1}} \mathbf{)}}$ Slope $\pm \mathbf{S E}$ & $\mathbf{R}^{\mathbf{2}}$ & $\boldsymbol{p}$ & $\boldsymbol{n}$ \\
\hline 2012 & 16.8 & $0.65 \pm 0.18$ & 0.57 & 0.005 & 12 \\
2013 & 19.9 & $0.50 \pm 0.19$ & 0.40 & 0.027 & 12 \\
2014 & 14.4 & $0.52 \pm 0.17$ & 0.46 & 0.015 & 12 \\
2015 & 13.1 & $0.89 \pm 0.09$ & 0.81 & $<0.001$ & 23 \\
2016 & 17.8 & $0.53 \pm 0.09$ & 0.74 & $<0.001$ & 15 \\
Pooled all year & & $0.62 \pm 0.06$ & 0.57 & $<0.001$ & 74 \\
\hline
\end{tabular}

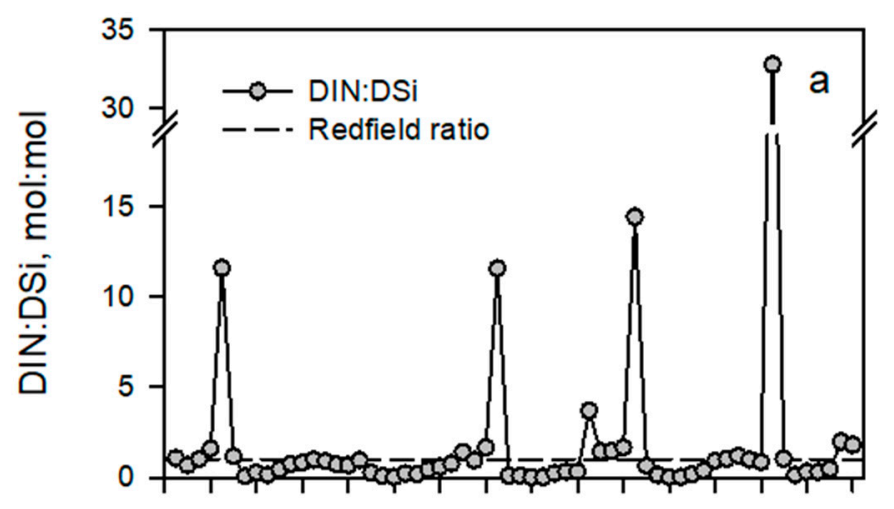

Figure 4. Cont. 

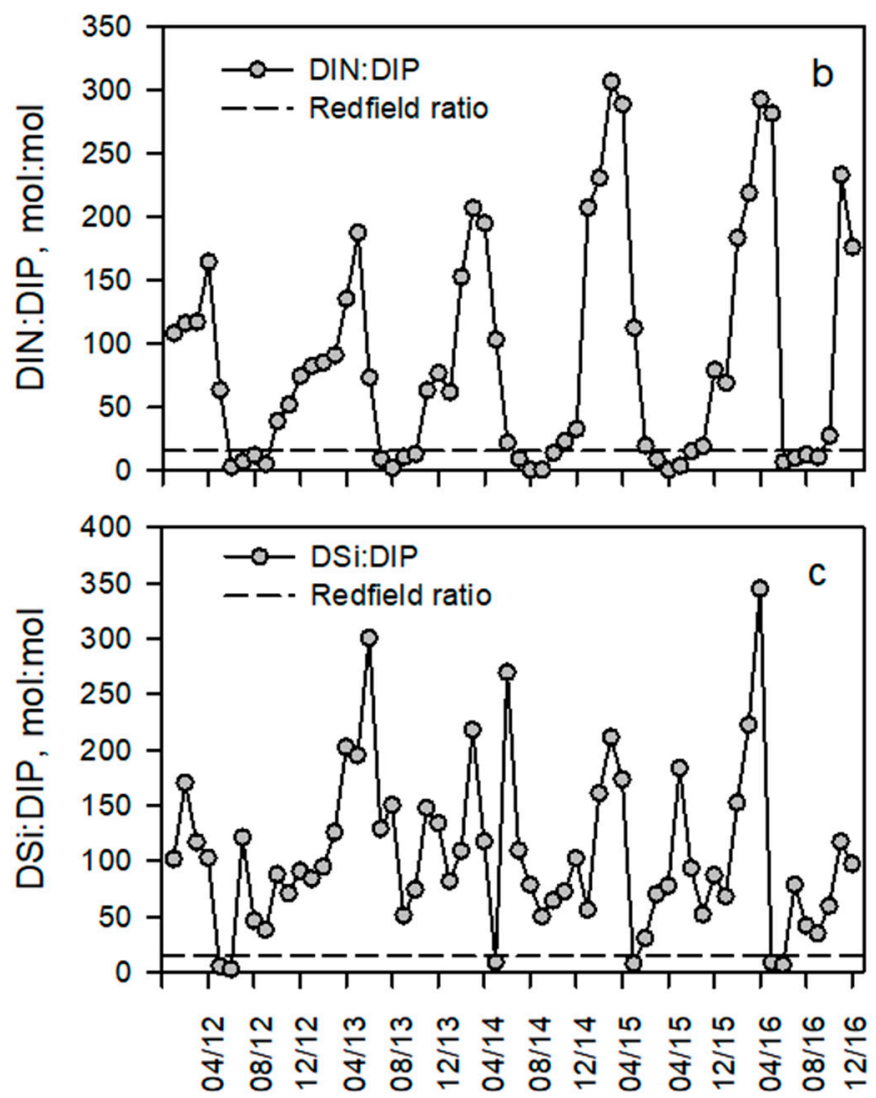

Figure 4. The stoichiometric DIN:DSi (a), DIN:DIP (b), and DSi:DIP (c) ratios determined monthly during the 2012-2016 period at the Nemunas River gauging station. Dashed lines indicate the theoretical Redfield ratio (DIN:DSi = 16:15, DIN:DIP = 16:1 and DSi:DIP = 15:1).

\subsection{Seasonal Trends of Discharge and Dissolved Inorganic and Particulate Nutrient Concentrations}

Seasonality influenced the Nemunas River discharge, as well as the concentration of inorganic and particulate nutrients throughout the study period (Table 2). From January-April, the Nemunas River discharge was 50\% above the annual average, while from June-October, it was $\sim 40 \%$ below the annual average. Due to seasonal effects, the concentrations of $\mathrm{NH}_{4}{ }^{+}$and $\mathrm{NO}_{\mathrm{x}}{ }^{-}$were $105 \%$ higher from December-March/April than their annual average. Meanwhile, from April/May-October, $\mathrm{NH}_{4}{ }^{+}$and $\mathrm{NO}_{\mathrm{x}}{ }^{-}$were 57 and $78 \%$ lower than their annual average, respectively. The concentration of DIP was typically higher than the mean (by $50 \%$ on average) from August-January and lower from March-July (by $\sim 60 \%$ on average). The concentration of DSi showed similar patterns to those of $\mathrm{N}$, but with a shorter period (three months), during which the values were lower (by 62\%) than the annual average. The results from the seasonal index analysis that was applied to the particulate concentrations revealed a strong consistency with that applied to inorganic forms, but with the opposite trends (Table 2). In fact, the concentrations of PN, PP and BSi increased above the average during spring-summer months, likely due to algal growth and the conversion of inorganic to particulate nutrient forms within the river. 
Table 2. Results of the seasonal index analysis. If the index is $>1$, it means that in the analysed month discharge or nutrient concentrations increased due to a seasonal influence, while if it is $<1$, it means that observed parameters decreased due to a seasonal influence.

\begin{tabular}{ccccccccc}
\hline Month & Discharge & $\mathbf{N H}_{\mathbf{4}}{ }^{+}$ & $\mathbf{N O}_{\mathbf{x}}{ }^{-}$ & DIP & DSi & PN & PP & BSi \\
\hline January & 1.30 & 2.53 & 2.21 & 1.31 & 1.10 & 0.68 & 0.89 & 0.82 \\
February & 1.61 & 2.19 & 2.62 & 0.92 & 1.28 & 0.38 & 0.55 & 0.38 \\
March & 1.48 & 1.37 & 2.19 & 0.60 & 1.30 & 0.48 & 0.67 & 0.37 \\
April & 1.58 & 0.81 & 1.87 & 0.48 & 0.93 & 0.79 & 1.05 & 0.71 \\
May & 1.09 & 0.36 & 0.40 & 0.15 & 0.10 & 2.00 & 1.45 & 2.31 \\
June & 0.74 & 0.38 & 0.08 & 0.18 & 0.30 & 2.07 & 1.54 & 2.02 \\
July & 0.62 & 0.37 & 0.09 & 0.73 & 0.84 & 1.57 & 1.13 & 1.50 \\
August & 0.52 & 0.27 & 0.07 & 1.37 & 1.14 & 1.60 & 1.44 & 0.97 \\
September & 0.54 & 0.25 & 0.17 & 1.77 & 0.96 & 1.34 & 1.28 & 1.45 \\
October & 0.63 & 0.54 & 0.51 & 1.63 & 1.38 & 0.70 & 1.30 & 0.38 \\
November & 0.91 & 1.10 & 0.94 & 1.61 & 1.32 & 0.69 & 0.67 & 0.49 \\
December & 1.08 & 2.10 & 1.37 & 1.25 & 0.32 & 0.50 & 0.53 & \\
\hline
\end{tabular}

The monthly concentration data series was tested for temporal trends by using both the seasonal and partial Mann-Kendall tests (Table 3). For the PMK test, the Nemunas River discharge was used as an explanatory variable. Thus, the nutrient concentrations were tested for trends, considering possible correlations with the trends in the discharge. According to the SMK test, a positive and statistically significant trend $(p<0.05)$ was detected for $\mathrm{NO}_{3}{ }^{-}$, while negative and statistically significant trends $(p<0.05)$ were detected for dissolved $\mathrm{NH}_{4}{ }^{+}$and the Nemunas River discharge. After applying the PMK test, only the $\mathrm{NO}_{3}{ }^{-}$trend resulted in statistical significance, while that of $\mathrm{NH}_{4}{ }^{+}$did not, suggesting its dependency on the discharge. Concerning particulate nutrient forms, PP temporal trends were statistically significant, positive and not dependent on the discharge. By contrast, PN displayed a negative trend that became highly significant after applying the PMK test. Biogenic Si did not show any significant $(p>0.05)$ temporal trends.

Table 3. Seasonal and partial Mann-Kendall trend analysis ( $p$-values). Positive (+) or negative (-) slope trend is reported in parenthesis.

\begin{tabular}{ccc}
\hline Variable & Seasonal Mann-Kendall & Partial Mann-Kendall \\
\hline Discharge & $0.017(-)$ & \\
$\mathrm{NH}_{4}{ }^{+}$ & $0.005(-)$ & 0.105 \\
$\mathrm{NO}_{3}{ }^{-}$ & $0.033(+)$ & $0.004(+)$ \\
$\mathrm{DSi}$ & 0.336 & 0.090 \\
$\mathrm{DIP}$ & 0.389 & 0.372 \\
$\mathrm{PN}$ & 0.056 & $0.021(-)$ \\
$\mathrm{PP}$ & $0.011(+)$ & $0.044(+)$ \\
$\mathrm{BSi}$ & 0.516 & 0.328 \\
\hline
\end{tabular}

\subsection{Dissolved Inorganic and Particulate Nutrient Contribution to the Total Load}

During 2012-2016, the mean annual load of TN transported from the watershed to the Nemunas River mouth was $44,208 \pm 12,677 \mathrm{t} \cdot \mathrm{yr}^{-1}$. There was a large interannual variability among loads, which differed by up to $50 \%$ (Figure 5 and Table 4 ). $\mathrm{NO}_{3}{ }^{-}$contributed nearly half $(48 \%)$ of the TN load, while the contributions of PN $(10 \%), \mathrm{NH}_{4}{ }^{+}(2 \%)$, and $\mathrm{NO}_{2}{ }^{-}(<1 \%)$ were minor. The Nemunas River basin exported a mean annual TP load of $1547 \pm 266 \mathrm{t} \cdot \mathrm{yr}^{-1}$ to the Curonian Lagoon. During the study period, nearly $50 \%$ of the TP load was transported as PP, while $36 \%$ was in the DIP form and the rest was in the dissolved organic form. The calculated annual DSi loads varied between 39,000 and $59,000 \mathrm{t} \cdot \mathrm{yr}^{-1}$ and represented the dominant fraction ( $84 \%$ on average) of the total $\mathrm{Si}$ loads transported to the lagoon $\left(59,048 \pm 10,770 \mathrm{t} \cdot \mathrm{yr}^{-1}\right.$, Table 4); the BSi loads averaged $\sim 9000 \mathrm{t} \cdot \mathrm{yr}^{-1}$. 

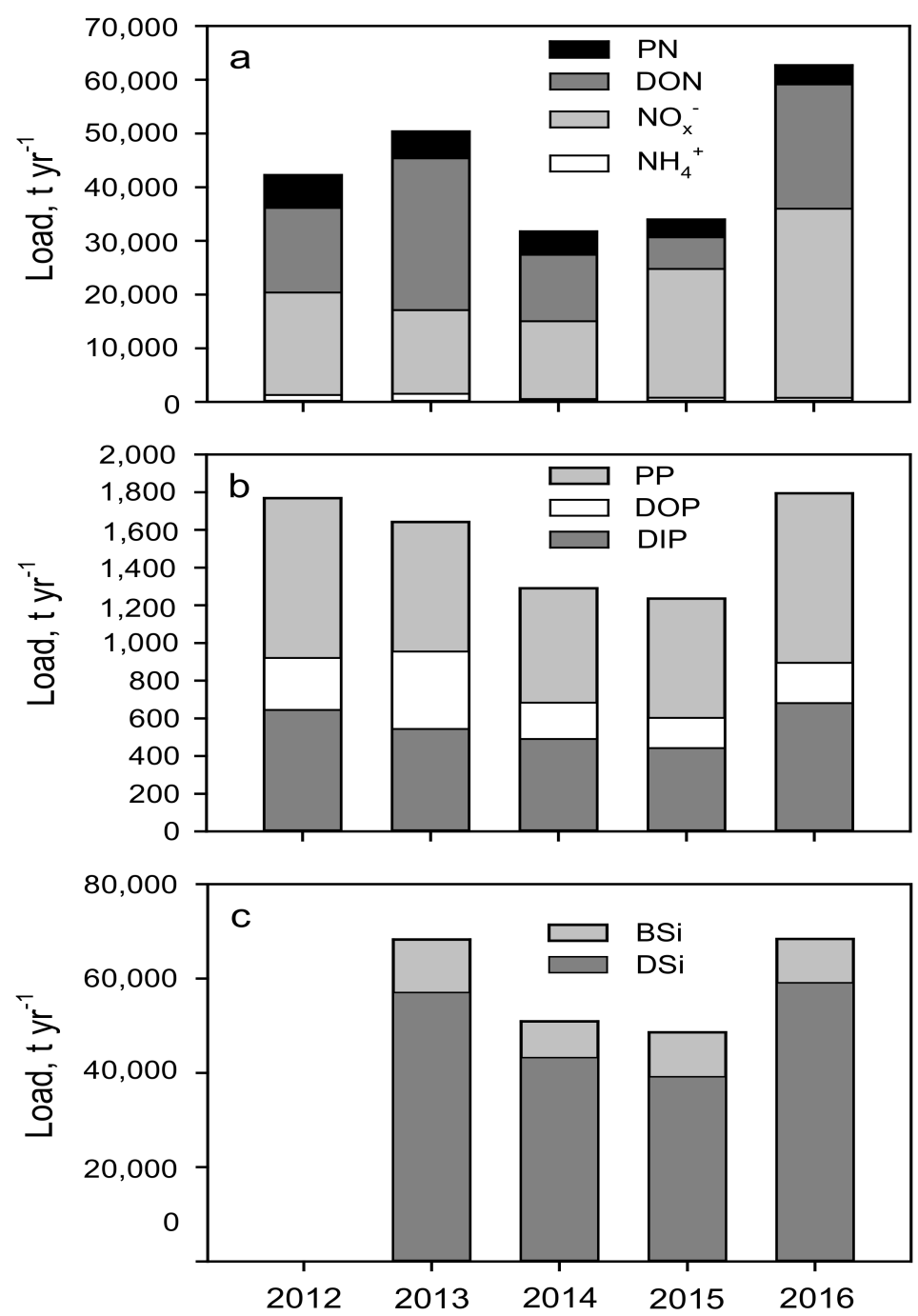

Figure 5. Annual loads of different inorganic and organic, dissolved and particulate forms of nitrogen (a), phosphorus (b), and silica (c) generated by the Nemunas River basin during the 2012-2016 period. During 2012, Si data were not measured.

Table 4. Annual loads of different forms of N, P, and Si during the 2012-2016 period.

\begin{tabular}{|c|c|c|c|c|c|c|}
\hline \multirow{2}{*}{ Nutrient } & \multirow{2}{*}{ Form } & \multicolumn{5}{|c|}{ Annual Nutrient Loads $\left(t \cdot \mathrm{yr}^{-1}\right)$} \\
\hline & & 2012 & 2013 & 2014 & 2015 & 2016 \\
\hline \multirow{6}{*}{$\mathrm{N}$} & $\mathrm{NH}_{4}^{+}$ & 1290 & 1528 & 564 & 808 & 786 \\
\hline & $\mathrm{NO}_{2}^{-}$ & 190 & 310 & 208 & 186 & 268 \\
\hline & $\mathrm{NO}_{3}^{-}$ & 18,889 & 15,254 & 14,274 & 23,792 & 34,934 \\
\hline & DON & 15,763 & 28,267 & 12,353 & 5853 & 23,167 \\
\hline & $\mathrm{PN}$ & 6128 & 5011 & 4353 & 3337 & 3525 \\
\hline & Total N & 42,260 & 50,370 & 31,752 & 33,976 & 62,680 \\
\hline \multirow{4}{*}{$\mathrm{P}$} & DIP & 645 & 544 & 491 & 442 & 682 \\
\hline & DOP & 276 & 411 & 193 & 161 & 214 \\
\hline & PP & 848 & 687 & 607 & 633 & 900 \\
\hline & Total P & 1769 & 1642 & 1291 & 1236 & 1795 \\
\hline \multirow{3}{*}{$\mathrm{Si}$} & DSi & 49,611 & 57,044 & 43,242 & 39,194 & 59,097 \\
\hline & BSi & - & 11,244 & 7668 & 9409 & 9294 \\
\hline & Total Si & - & 68,288 & 50,910 & 48,603 & 68,392 \\
\hline
\end{tabular}




\section{Discussion}

\subsection{Seasonal and Interannual Variations of Discharge, Nutrient Concentrations and Stoichiometry}

Mid-term (over some consecutive years) and frequent (at least monthly) monitoring of rivers that drain large watersheds allows to provide reliable datasets to analyse the temporal trends in discharge and nutrient transport [34]. This monitoring time span and frequency requirements are due to three main reasons: (1) Climatic microcycles may last for multiple years and are characterized by prolonged dry or wet phases; (2) climate, through hydrology, affects nutrient cycles; and (3) the effects of ongoing climate changes interact with those of implementation of policy directives that target nutrient reduction (e.g., land use, sewage water treatment plants, and the use of fertilizers) [36,50-52]. Due to reasons (1) and (2), a one- or two-year sampling program may fall in unusually low or high discharge periods that are not representative of a climatic microcycle and therefore lead to an incorrect conclusion regarding discharge (and nutrient) trends. Due to reason (3), long-term temporal series (10-30 years) are needed to disentangle the effects of climate from those of socio-economic ongoing changes.

The results from this study suggest that the discharge and nutrient concentrations at the Nemunas River closing section displayed a strong and regular seasonality (see Seasonal index in Table 2). The discharge was uncoupled from precipitation, suggesting air temperature, plant cover, and activity and evapotranspiration as factors that regulate the link between precipitation and river flow [53]. The Nemunas River discharge generally peaked in spring, coinciding with snowmelt, and reached a minimum in summer, coinciding with the highest levels of precipitation and air temperatures (Figure 2). Similar results were described for the Daugava River, which has a comparable annual discharge and lies in the same geographical area [54]. The discharge is affected by a combination of precipitation patterns/intensities and evapotranspiration/accumulation in groundwater, as well as by steep changes in temperature that either drive snow/ice melt or water freezing [55]. The air temperature therefore co-regulates river discharge, and the discharge affects the pattern of nutrient delivery from the watershed to the river.

During 2012-2016, the annual discharge was below the historical records, a result that aligns with that predicted by Jakimavičius and Kriaučiūnienè [41] via climate change models. The different variabilities between precipitation and discharge can be explained by processes that occur within the Nemunas watershed. In particular, the large soil surface, which is covered by active vegetation during summer, may efficiently buffer the discharge from the effects of variable precipitation patterns by varying the evapotranspiration rates, resulting in constant flows [56]. Due to the absence of active vegetation in cultivated land, this does not occur during winter.

All of the dissolved inorganic nutrients underwent pronounced variations during the 5-year study period, with alternating peaks and minima that were opposite to those recorded for their particulate forms. The seasonal trends were stable for $\mathrm{NH}_{4}{ }^{+}$and $\mathrm{NO}_{3}{ }^{-}$, while they were more variable for DIP and DSi. Within the study period, only $\mathrm{NO}_{3}{ }^{-}$increased significantly, a trend that is opposite to the predicted trend and desired political actions [50]. According to recent inventories, agriculture and the associated conversion of pastures into croplands remain the main contributors of $\mathrm{N}$ loads transported by the Nemunas River [50]. A major fraction of this $\mathrm{N}$ (and P) is generated from the section of the Nemunas watershed that belongs to Belarus, while a minor fraction has a natural origin [50,57]. Agricultural activities affect hydrology and nutrient cycling within croplands by altering filtration, groundwater recharge, base flow, and run-off from catchments [58]. At the closing section of the Nemunas River, $\mathrm{NO}_{3}{ }^{-}$dynamics were comparable to those recorded in other Baltic Sea rivers, with peaks during winter/spring and minima during summer/autumn [54,59]. During colder months, $\mathrm{NO}_{3}{ }^{-}$loss from the watershed is expected to be higher, as biogeochemical processes that are able to transform $\mathrm{NO}_{3}{ }^{-}$into organic or molecular $\mathrm{N}$ via uptake or denitrification are limited, while the retention time is reduced by precipitation and snow melting. In summer, high $\mathrm{N}$ uptake by crops and other vegetation, denitrification processes in soils and $\mathrm{N}$ uptake by phytoplankton all drive the lower downstream flux. The relationship between the riverine $\mathrm{NO}_{3}{ }^{-}$concentration and discharge 
varied among years, likely due to different leaching from the land. We expect that during the driest years, the water table migrates vertically, allowing air to penetrate deeper within soils and nitrification processes to occur. Nitrate may accumulate within dry soils during summer and then be suddenly and massively transported when it starts raining, resulting in proportionally higher transport per unit discharge compared to wetter years (e.g., [51]). In fact, during wetter years, when longer periods of soil saturation and anoxia and higher rates of denitrification are expected, proportionally lower nitrate export occurs [60].

The variability of the concentrations of DIP and DSi was comparatively smaller, suggesting limited control by processes within the watershed (on both elements) or a constant background input from sewage treatment plants $(\mathrm{P})$. Dissolved $\mathrm{Si}$ is also very important in the Curonian lagoon since it is necessary for diatom growth, which is a dominant group in spring phytoplankton [61]. The DSi concentrations were highest during cold periods due to weathering of bedrock and groundwater transport. They decreased in late spring, likely due to Si uptake by both cultivated plants and riverine communities of blooming diatoms [56]. The same trends were found in other Baltic rivers [54,62]. The nutrient concentration ranges in the Nemunas River were similar to those reported in the Daugava River [54].

The ecological stoichiometry of the three nutrients is central to the analysis of watersheds and nutrient export to coastal areas $[63,64]$. Within the BONUS program, the COCOA project (Nutrient Cocktails in Coastal zones of the Baltic Sea, 2014-2017) targeted the origin, transport, and fate of the three nutrients in different environments of the Baltic Sea. This approach is important since the relative availability of nutrients, much more than their single abundances, regulates algal blooms or drives the efficiency of decomposition processes [65]. Frequent cyanobacterial blooms in the shallow lagoons along the coast of the Baltic Sea suggest favourable nutrient ratio for their dominance $[66,67]$. Our results show that the seasonality of nutrient transport resulted in a variable ecological stoichiometry of N, Si, and P. In general, we observed a large excess of $\mathrm{N}$ in autumn, winter, and spring (DIN:DIP > 16), but a marked $\mathrm{N}$ deficiency (and to a minor extent of $\mathrm{Si}$ ) from May to August during the five analysed years. With respect to downstream water bodies (Curonian Lagoon and Baltic Sea), this strong N and Si summer limitation may favour the succession of phytoplankton communities from diatom-dominated (spring) to cyanobacteria-dominated (summer) [13,24]. During warm months, cyanobacteria have a competitive advantage as they do not require silica for their exoskeleton and can fix relatively inert dinitrogen $\left(\mathrm{N}_{2}\right)$ when $\mathrm{N}$ is limiting. Any P excess may therefore favour their development [31]. Recent findings suggest that cyanobacteria dominance can offset the attenuation of $\mathrm{N}$ load by the Curonian lagoon via denitrification, anammox, uptake, and internal storage, while enhancing its export to the Baltic Sea [68]. Moreover, cyanobacteria blooms have large economic impacts in the Curonian Lagoon due to high rates of respiration in the water that can favour night-time hypoxia $\left(<62.5 \mu \mathrm{M} \cdot \mathrm{O}_{2},[27]\right)$ and mortality of benthic organisms and fish [27]. The present study suggests that future political actions should target further P reductions in the Nemunas watershed to tackle the unbalanced nutrient stoichiometry [30].

\subsection{Nutrient Trends: Past, Present and Ongoing Changes}

Compared to previously published data, the loads of dissolved inorganic as well as the total forms of N and P measured from 2012-2016 have changed, while to our knowledge there is no previously published information on Si (Table 5). From 1997-2002 to 2012-2016, the $\mathrm{NO}_{3}{ }^{-}$loads decreased moderately, whereas the load reductions of $\mathrm{NH}_{4}{ }^{+}$and DIP were much more noticeable from the 1986-1991 and 1980-1993 datasets, respectively (Table 4). Since riverine discharge remained relatively similar, we address the substantial decrease of $\mathrm{NH}_{4}{ }^{+}$and DIP loads to the modernization of water treatment and construction of new sewage treatment plants after the entrance of Lithuania into the European Union. Interestingly, the socio-economic changes in society such as the increasing use of phosphorus-free detergents will be responsible for further decrease of $\mathrm{P}$ inputs to natural environments from households [18]. The trend in the DSi loads remains rather unclear. In the present 
study, the estimated nutrient loads were similar to those reported for rivers entering the Gulf of Riga [54]. Humborg et al. [69] and Conley et al. [70] showed that the DSi concentrations and loads tended to decrease during the past few decades in other large tributaries of the Baltic Sea due to river damming, other anthropogenic activities in catchments, or changes in the composition of detergents. These changes in loads might correspond to an increasing $\mathrm{Si}$ limitation over $\mathrm{N}$, which may result in a shift from diatom to green algae blooms during spring.

Table 5. Published average annual discharge and nutrient loads to the Baltic Sea measured in proximity to or at the mouth of the Nemunas River during the 1980-2016 period.

\begin{tabular}{|c|c|c|c|c|c|c|c|c|}
\hline \multirow{2}{*}{ Period } & \multirow{2}{*}{$\begin{array}{c}\text { Flow } \\
\left(\mathrm{km}^{3} \mathrm{yr}^{-1}\right)\end{array}$} & \multicolumn{5}{|c|}{ Nutrient Loads $\left(t \cdot \mathrm{yr}^{-1}\right)$} & \multirow{2}{*}{ DIN:DIP } & \multirow{2}{*}{ Reference } \\
\hline & & $\mathrm{NO}_{3}{ }^{-}$ & $\mathrm{NH}_{4}{ }^{+}$ & TN & DIP & TP & & \\
\hline 1980-1993 & 20.5 & 31,650 & & 58,340 & 4140 & 5410 & 8 & {$[21]$} \\
\hline 1986-1991 & & 9702 & 8601 & & 4573 & & 4 & [15] \\
\hline 1992-1996 & & 20,604 & 5983 & & 969 & & 27 & {$[15]$} \\
\hline 1997-2002 & $16.6^{*}$ & 25,048 & 2202 & & 636 & & 43 & {$[15]$} \\
\hline 1997-2008 & $16.6^{*}$ & & & 46,335 & & 2635 & & [30] \\
\hline $2000-2006$ & 15.9 * & & & 37,620 & & & & [29] \\
\hline $2008-2010$ & 18.3 * & & & 41,546 & & 1834 & & [30] \\
\hline $2012-2016$ & 16.4 & 21,429 & 995 & 44,208 & 561 & 1547 & 40 & This study \\
\hline
\end{tabular}

* Long-term flow at the Nemunas River gauging station provided by The Lithuanian Hydrometeorological Service.

In Lithuania, the updated HELCOM compilation of trend analyses in nutrient loads projected a decrease of $1142 \mathrm{t}$ of TN and $63.4 \mathrm{t}$ of TP during the 1995-2010 period [30]. Our results show that until 2014, the annual loads of TN and TP followed this trend even faster than expected. However, the trend changed later, when TN started to increase. To meet the targets for sustainable total $\mathrm{N}$ and P loads to the Baltic Sea, Lithuania agreed to reduce annual TN and TP loads to 11,750 $\mathrm{t}$ and $880 \mathrm{t}$, respectively, by 2021 [71]. These targets appear to be realistic for P, but they remain challenging for $\mathrm{TN}$, as the mean load calculated in the present study exceeds the projected threshold by $\sim 30 \%$. Šileika et al. [29] suggest that converting $20 \%$ of arable land to pasture, together with sewage treatment plant improvements, would reduce the yearly TN export to $12,000 \mathrm{t}$, which is close to the target set for Lithuania. Improvement of agricultural practices would not necessary result in lower contribution of diffuse sources to $\mathrm{N}$ loads as the transfer of $\mathrm{N}$ from arable land to surface and ground water largely depends on storage and immobilisation processes within soils [36,52]. During the Soviet Union period, the low cost and the intensive application of $\mathrm{N}$ fertilizers in agriculture likely caused $\mathrm{N}$ accumulation in soils. Leaching of previously accumulated fertilizers can contribute nutrient concentrations in rivers for decades, as was demonstrated in southern Europe watersheds [52]. Such elevated background input may mask the expected positive effects of more sustainable agricultural practices (e.g., nutrient reduction). According to the Lithuanian Department of Statistics, over the last decade, the pasture area has remained relatively constant, while cattle number decreased by $7 \%$ from 2004 to 2016 and croplands have increased by $42 \%$ in the same period (Figure 6). The changes in agricultural practices coincided with new subsidies after the entrance of Lithuania in the European Union in 2004; as market price and subsidies for crops increased, farmers maintained or expanded this agricultural practice. Furthermore, land cover changes are accompanied by increased application of fertilizers, which can lead to higher leaching of $\mathrm{N}$ in dry years, when crop yields are low [10]. Modelled future intensification scenarios of agricultural practices for selected catchments in the Southeast Baltic region (Poland and Baltic States) reveal an increase in N loading by nearly 30\% [72]. Climate change may also result in increased crop production, especially in Belarus, further stimulating both the conversion of forests or pastures into arable land as well as the use of fertilizers. Under such a scenario, the achievements of nutrient reduction plans along the Nemunas watershed become challenging for downstream countries as Lithuania due to major anthropogenic $\mathrm{N}$ and $\mathrm{P}$ loadings generated upstream, in Belarus. Nevertheless, trends in net anthropogenic $\mathrm{N}$ and $\mathrm{P}$ 
inputs can be confounded by ongoing regional changes of lifestyles [14,73]. Therefore, future studies addressing the genesis of nutrient loads in the Nemunas watershed should integrate the combined effects of climate, agriculture, and socio-economic changes.

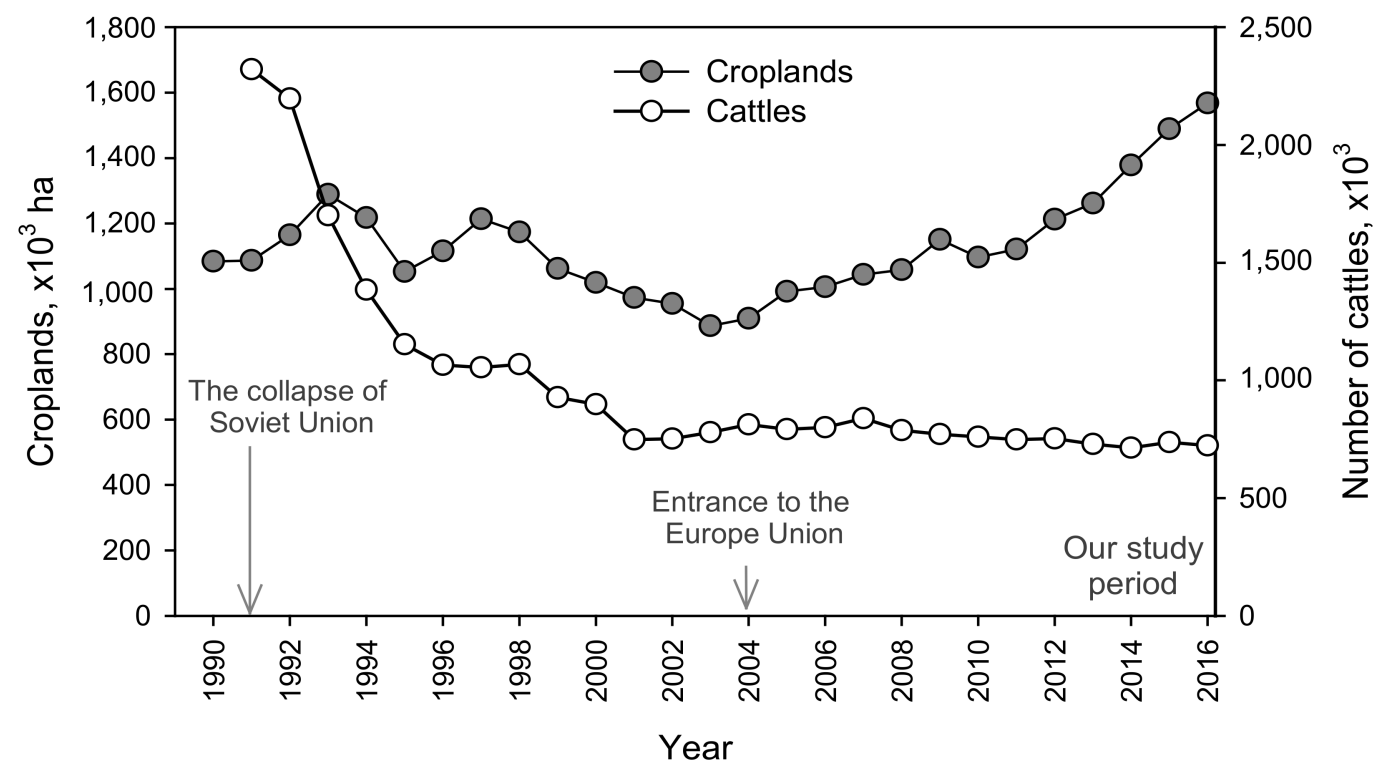

Figure 6. Dynamic of cropland area (grey circles) and number of cattle (open circles) in the territory of Lithuanian Republic during 1990-2016. Inventories are based on observation by the Lithuanian Department of Statistics.

A major fraction of nutrient loads from large catchments to the Baltic Sea passes through large estuarine systems, such as the Curonian, Oder, and Vistula lagoons, where nutrients can be partly retained [21,71]. It was demonstrated that $14-88 \%$ of the TN loads and $27-89 \%$ of the TP loads were retained during their transport through the large Baltic lagoons [24,74]. Within lagoons, retention can be sometimes offset by cyanobacterial blooms, which result in large export of algal cells, may induce bottom anoxia, and may favour $P$ release from anoxic sediment and its transport to the Baltic Sea $[24,68,75]$. The latter point demonstrates that the TN and TP loads can differ substantially depending on whether they are measured at the end of the catchment (the river closing section) or at the interface between the estuary and the Baltic Sea (the lagoon mouth). However, in the Baltic Sea Action Plan (BSAP) adopted by HELCOM, the maximal allowable nutrient loads to the Baltic Sea are measured at the river's gauging section, excluding the processes within estuaries. This generally emphasizes the need to review BSAP and adapt regional BSAP-related goals [76]. In fact, the N and P reduction targets for different Baltic Sea countries could be achieved more rapidly if retention processes in transitional waters are included in models and calculations. Continuous monitoring of major rivers, such as the Nemunas, and of the processes that occur in downstream environments, such as estuarine systems, is of key importance as recent studies have demonstrated frequent switches between the role of transitional aquatic environments as nutrient sinks and sources [24,27,75].

\section{Conclusions}

The results of this study demonstrate the need of long-term monitoring of nutrients delivered from watersheds to coastal areas, particularly in critical regions, such as the Baltic macroregion. Here, climatic anomalies and ongoing changes in socio-economic factors and agricultural activities may affect hydrological cycles, river discharge, and nutrient transport. Moreover, increasing temperatures may directly affect future investments of farmers and crop production, as well as indirectly stimulate the use of fertilizers. Lithuania has agreed to reduce significantly the $\mathrm{N}$ and $\mathrm{P}$ loads to the Baltic Sea, but we present data suggesting that the expected reduction may be realistic only for P. Total P 
decreased substantially in 2012-2016 compared to previous decades, while the loads of TN appeared to fluctuate around similar values, which may be due to the large pool of $\mathrm{N}$ stored within soil or in groundwater that is slowly released, despite policy implementation [36,52]. This research contribution is among the few studies that report $\mathrm{Si}$ together with $\mathrm{P}$ and $\mathrm{N}$ data. The ecological stoichiometry of exported nutrients is important as it may affect the function of downstream estuaries, lagoons, and coastal areas, as well as reverse their role as nutrient sinks. The data presented in this study suggest a constant summer $\mathrm{N}$ limitation in the cocktail of nutrients exported from the Nemunas watershed, which should be considered in future nutrient reduction plans. At present, the low summer N:P ratio favours cyanobacteria blooms in the Curonian lagoon, which result in increased particulate matter production and subsequent export to the Baltic Sea

Author Contributions: I.V.-L carried out water sampling and analytical analysis, and wrote a first draft. M.Z. contributed to data interpretation and paper writing. L.S.-V. performed the statistical analysis of data. M.B. contributed to data interpretation and revised the paper draft.

Funding: This research was funded by BONUS grant [No. BONUS-2/2014]. The APC was funded by the European Social Fund according to the activity 'Improvement of researchers' qualification by implementing world-class R\&D projects' of Measure [No. 09.3.3-LMT-K-712-01-0069].

Acknowledgments: This work was supported by the BONUS project "Nutrient Cocktails in Coastal zones of the Baltic Sea (COCOA)" (No. BONUS-2/2014). We kindly acknowledge Jolita Petkuvienè and Petras Zemlys for laboratory and data analysis. We thank the Lithuanian Marine Research Department of the Ministry of Environment for Nemunas River discharge data.

Conflicts of Interest: The authors declare no conflict of interest.

\section{References}

1. Howarth, R.W.; Billen, G.; Swaney, D.; Townsend, A.; Jaworksi, N.; Lajtha, K.; Downing, J.A.; Elmgren, R.; Caraco, N.; Jordan, T.; et al. Regional nitrogen budgets and riverine $\mathrm{N}$ and $\mathrm{P}$ fluxes for the drainages to the North Atlantic Ocean: Natural and human influences. Biogeochemistry 1996, 35, 75-139. [CrossRef]

2. Conley, D.J. Terrestrial ecosystems and the global biogeochemical silica cycle. Glob. Biogeochem. Cycles 2002, 16. [CrossRef]

3. Galloway, J.N.; Aber, J.D.; Erisman, J.W.; Seitzinger, S.P.; Howarth, R.W.; Cowling, E.B.; Cosby, B.J. The nitrogen cascade. AIBS Bull. 2003, 53, 341-356. [CrossRef]

4. Erisman, J.W.; Sutton, M.A.; Galloway, J.; Klimont, Z.; Winiwarter, W. How a century of ammonia synthesis changed the world. Nat. Geosci. 2008, 1, 636. [CrossRef]

5. Schipanski, M.E.; Bennett, E.M. The influence of agricultural trade and livestock production on the global phosphorus cycle. Ecosystems 2012, 15, 256-268. [CrossRef]

6. Conley, D.J.; Paerl, H.W.; Howarth, R.W.; Boesch, D.F.; Seitzinger, S.P.; Havens, K.E.; Lancelot, C.; Likens, G.E. Controlling eutrophication: Nitrogen and phosphorus. Science 2009, 323, 1014-1015. [CrossRef] [PubMed]

7. Bartoli, M.; Racchetti, E.; Delconte, C.A.; Sacchi, E.; Soana, E.; Laini, A.; Longhi, D.; Viaroli, P. Nitrogen balance and fate in a heavily impacted watershed (Oglio River, Northern Italy): In quest of the missing sources and sinks. Biogeosciences 2012, 9, 361-373. [CrossRef]

8. McCrackin, M.L.; Gustafsson, B.G.; Hong, B.; Howarth, R.W.; Humborg, C.; Savchuk, O.P.; Svanbäck, A.; Swaney, P.D. Opportunities to reduce nutrient inputs to the Baltic Sea by improving manure use efficiency in agriculture. Reg. Environ. Chang. 2018. [CrossRef]

9. Struyf, E.; Smis, A.; Van Damme, S.; Garnier, J.; Govers, G.; Van Wesemael, B.; Conley, D.J.; Batelaan, O.; Frot, E.; Clymans, W.; et al. Historical land use change has lowered base-line silica mobilization from landscapes. Nat. Commun. 2010, 1, 129. [CrossRef] [PubMed]

10. Huttunen, I.; Lehtonen, H.; Huttunen, M.; Piirainen, V.; Korppoo, M.; Veijalainen, N.; Viitasalo, M.; Vehviläinen, B. Effects of climate change and agricultural adaptation on nutrient loading from Finnish catchments to the Baltic Sea. Sci. Total Environ. 2015, 529, 168-181. [CrossRef] [PubMed]

11. Ockenden, M.C.; Deasy, C.E.; Benskin, C.M.H.; Beven, K.J.; Burke, S.; Collins, A.L.; Evans, R.; Falloon, P.D.; Forber, K.J.; Hiscock, K.M.; et al. Changing climate and nutrient transfers: Evidence from high temporal resolution concentration-flow dynamics in headwater catchments. Sci. Total Environ. 2016, 548-549, 325-339. [CrossRef] [PubMed] 
12. Bricker, S.B.; Longstaff, B.; Dennison, W.; Jones, A.; Boicourt, K.; Wicks, C.; Woerner, J. Effects of nutrient enrichment in the nation's estuaries: A decade of change. Harmful Algae 2008, 8, 21-32. [CrossRef]

13. Bukaveckas, P.A.; Lesutienè, J.; Gasiūnaite, Z.R.; Ložys, L.; Olenina, I.; Pilkaitytè, R.; Pūtys, Ž.; Tassone, S.; Wood, J. Microcystin in aquatic food webs of the Baltic and Chesapeake Bay regions. Estuar. Coast Shelf Sci. 2017, 191, 50-59. [CrossRef]

14. Hägg, H.E.; Lyon, S.W.; Wällstedt, T.; Mörth, C.M.; Claremar, B.; Humborg, C. Future nutrient load scenarios for the Baltic Sea due to climate and lifestyle changes. Ambio 2014, 43, 337-351. [CrossRef] [PubMed]

15. Sileika, A.S.; Stålnacke, P.; Kutra, S.; Gaigalis, K.; Berankiene, L. Temporal and spatial variation of nutrient levels in the Nemunas River (Lithuania and Belarus). Environ. Monit. Assess. 2006, 122, 335-354. [CrossRef] [PubMed]

16. Galloway, J.N.; Townsend, A.R.; Erisman, J.W.; Bekunda, M.; Cai, Z.; Freney, J.R.; Martinelli, L.A.; Seitzinger, S.P.; Sutton, M.A. Transformation of the nitrogen cycle: Recent trends, questions, and potential solutions. Science 2008, 320, 889-892. [CrossRef] [PubMed]

17. Mallin, M.A.; McIver, M.R.; Wells, H.A.; Parsons, D.C.; Johnson, V.L. Reversal of eutrophication following sewage treatment upgrades in the New River Estuary, North Carolina. Estuar. Coast 2005, 28, 750-760. [CrossRef]

18. Saaltink, R.; van der Velde, Y.; Dekkera, S.D.; Lyon, S.W.; Dahlkee, H.E. Societal, land cover and climatic controls on river nutrient flows into the Baltic Sea. J. Hydrol. Reg. Stud. 2014, 1, 44-56. [CrossRef]

19. Humborg, C.; Pastuszak, M.; Aigars, J.; Siegmund, H.; Mörth, C.M.; Ittekkot, V. Decreased silica land-sea fluxes through damming in the Baltic Sea catchment-significance of particle trapping and hydrological alterations. Biogeochemistry 2006, 77, 265-281. [CrossRef]

20. Billen, G.; Garnier, J.; Ficht, A.; Cun, C. Modeling the response of water quality in the Seine river estuary to human activity in its watershed over the last 50 years. Estuar. Coast 2001, 24, 977-993. [CrossRef]

21. Stålnacke, P.; Grimvall, A.; Sundblad, K.; Tonderski, A. Estimation of riverine loads of nitrogen and phosphorus to the Baltic Sea, 1970-1993. Environ. Monit. Assess. 1999, 58, 173-200. [CrossRef]

22. Rabalais, N.N.; Turner, R.E.; Scavia, D. Beyond Science into Policy: Gulf of Mexico Hypoxia and the Mississippi River: Nutrient policy development for the Mississippi River watershed reflects the accumulated scientific evidence that the increase in nitrogen loading is the primary factor in the worsening of hypoxia in the northern Gulf of Mexico. AIBS Bull. 2002, 52, 129-142. [CrossRef]

23. Heisler, J.P.; Gilbert, J.; Burkholder, J.; Anderson, D.; Cochlan, W.; Dennison, W.; Dortch, Q.; Gobler, C.J.; Heil, C.; Humphries, E.; et al. Eutrophication and harmful algal blooms: A scientific consensus. Harmful Algae 2008, 8, 3-13. [CrossRef] [PubMed]

24. Vybernaite-Lubiene, I.; Zilius, M.; Giordani, G.; Petkuviene, J.; Vaiciute, D.; Bukaveckas, P.A.; Bartoli, M. Effect of algal blooms on retention of N, Si and P in Europe's largest coastal lagoon. Estuar. Coast Shelf Sci. 2017, 194, 217-228. [CrossRef]

25. Karlson, K.; Rosenberg, R.; Bbonsdorff, E. Temporal and spatial large-scale effects of eutrophication and oxygen deficiency on benthic fauna in Scandinavian and Baltic waters: A review. Oceanogr. Mar. Biol. 2002, 40, 427-489.

26. Vahtera, E.; Conley, D.J.; Gustafsson, B.G.; Kuosa, H.; Pitkanen, H.; Savchuk, O.P.; Tamminen, T.; Viitasalo, M.; Voss, M.; Wasmund, N.; et al. Internal ecosystem feedbacks enhance nitrogen-fixing cyanobacteria blooms and complicate management in the Baltic Sea. Ambio 2007, 36, 186-194. [CrossRef]

27. Zilius, M.; Bartoli, M.; Bresciani, M.; Katarzyte, M.; Ruginis, T.; Petkuviene, J.; Lubiene, I.; Giardino, C.; Bukaveckas, P.A.; de Wit, R.; et al. Feedback mechanisms between cyanobacterial blooms, transient hypoxia, and benthic phosphorus regeneration in shallow coastal environments. Estuar. Coast 2014, 37, 680-694. [CrossRef]

28. Fleming-Lehtinen, V.; Andersen, J.H.; Carstensen, J.; Łysiak-Pastuszak, E.; Murray, C.; Pyhälä, M.; Laamanen, M. Recent developments in assessment methodology reveal that the Baltic Sea eutrophication problem is expanding. Ecol. Indic. 2015, 48, 380-388. [CrossRef]

29. Šileika, A.S.; Wallin, M.; Gaigalis, K. Assessment of nitrogen pollution reduction options in the river Nemunas (Lithuania) using FyrisNP model. J. Environ. Eng. Landsc. 2013, 21, 141-151. [CrossRef]

30. Helsinki Commission. Updated Fifth Baltic Sea pollution load compilation (PLC-5.5). In Baltic Sea Environment Proceedings; Helsinki Commission: Helsinki, Finland, 2015. 
31. Paerl, H.W.; Hall, N.S.; Calandrino, E.S. Controlling harmful cyanobacterial blooms in a world experiencing anthropogenic and climatic-induced change. Sci. Total Environ. 2011, 409, 1739-1745. [CrossRef] [PubMed]

32. Paerl, H.W.; Otten, T.G. Harmful cyanobacterial blooms: Causes, consequences, and controls. Microb. Ecol. 2013, 65, 995-1010. [CrossRef] [PubMed]

33. Schindler, D.W. The dilemma of controlling cultural eutrophication of lakes. Proc. Biol. Sci. 2012, 279, 4322-4333. [CrossRef] [PubMed]

34. Bouraoui, F.; Grizzetti, B. Long term change of nutrient concentrations of rivers discharging in European seas. Sci. Total Environ. 2011, 409, 4899-4916. [CrossRef] [PubMed]

35. Voss, M.; Dippner, J.; Humborg, C.; Korth, F.; Neumann, T.; Hürdler, J.; Schernewski, G.; Venohr, M. History and scenarios of future development of Baltic Sea eutrophication. Estuar. Coast Shelf Sci. 2011, 92, 307-322. [CrossRef]

36. Garnier, J.; Ramarson, A.; Thieu, V.; Némery, J.; Théry, S.; Billen, G.; Coynel, A. How can water quality be improved when the urban waste water directive has been fulfilled? A case study of the Lot river (France). Environ. Sci. Pollut. Res. Int. 2018, 12, 11924-11939. [CrossRef] [PubMed]

37. Povilaitis, A.; Šileika, A.; Deelstra, J.; Gaigalis, K.; Baigys, G. Nitrogen losses from small agricultural catchments in Lithuania. Agr. Ecosyst. Environ. 2014, 198, 54-64. [CrossRef]

38. Egge, J.K.; Aksnes, D.L. Silicate as regulating nutrient in phytoplankton competition. Mar. Ecol. Prog. Ser. 1992, 83, 281-289. [CrossRef]

39. Gailiušis, B.; Jablonskis, J.; Kovalenkovienė, M. The Lithuanian rivers. In Hydrography and Runoff; Lithuanian Energy Institute: Kaunas, Lithuania, 2001; 792p, ISBN 9986-492-64-5.

40. Vaitkuviene, D.; Dagys, M. CORINE 2006 Land Cover, Lithuania; Technical report No. CLC2006, Second Verification; Institute of Ecology of Vilnius University: Vilnius, Lithuania, 2008.

41. Jakimavičius, D.; Kriaučiūnienè, J. The climate change impact on the water balance of the Curonian Lagoon. Water Resour. 2013, 40, 120-132. [CrossRef]

42. Grasshoff, K.; Ehrhardt, M.; Kremling, K. Methods of Seawater Analysis; Verlag Chemie: Weinheim, Germany, 1983.

43. Bower, C.E.; Holm-Hansen, T. A salicylate-hypochlorite method for determining ammonia in seawater. Can. J. Fish Aquat. Sci. 1980, 37, 794-798. [CrossRef]

44. Koroleff, F. Determination of Phosphorus. In Methods of Seawater Analysis; Verlag Chemie: Weinheim, Germany, 1983.

45. Aspila, K.I.; Agemian, H.; Chau, A.S. A semi-automated method for the determination of inorganic, organic and total phosphate in sediments. Analyst 1976, 101, 187-197. [CrossRef] [PubMed]

46. Ragueneau, O.; Savoye, N.; Del Amo, Y.; Cotton, J.; Tardiveau, B.; Leynaert, A. A new method for the measurement of biogenic silica in suspended matter of coastal waters: Using Si: Al ratios to correct for the mineral interference. Cont. Shelf Res. 2005, 25, 697-710. [CrossRef]

47. Helsinki Commission. The Fourth Baltic Sea Pollution Load Compilation (PLC-4). In Baltic Sea Environment Proceedings; Helsinki Commission: Helsinki, Finland, 2004.

48. Hirsch, R.M.; Slack, J.R.; Smith, R.A. Techniques for trend assessment for monthly water quality data. Water Resour. Res. 1982, 18, 107-121. [CrossRef]

49. Libiseller, C.; Grimvall, A. Performance of partial Mann-Kendall tests for trends detection in the presence of covariates. Environmetrics 2002, 13, 71-84. [CrossRef]

50. Bauer, A. Status of Nutrient Bookkeeping in the Baltic Sea Countries. Report Document Texte 95/2015. 2105. Available online: http:/ / www.umweltbundesamt.de/publikationen/status-of-nutrient-bookkeeping-inthe-baltic-sea.pdf (accessed on 15 November 2015).

51. Dupas, R.; Jomaa, S.; Musolff, A.; Borchardt, D.; Rode, M. Disentangling the influence of hydroclimatic patterns and agricultural management on river nitrate dynamics from sub-hourly to decadal time scales. Sci. Total Environ. 2016, 571, 791-800. [CrossRef] [PubMed]

52. Romero, E.; Le Gendre, R.; Garnier, J.; Billen, G.; Fisson, C.; Silvestre, M.; Ph, R. Long-term water quality in the lower Seine: Lessons learned over 4 decades of monitoring. Environ. Sci. Policy 2016, 58, 141-154. [CrossRef] 
53. Yin, J.; He, F.; Xiong, Y.J.; Qiu, G.Y. Effects of land use/land cover and climate changes on surface runoff in a semi-humid and semi-arid transition zone in northwest China. Hydrol. Earth Syst. Sci. 2017, 21, 183. [CrossRef]

54. Laznik, M.; Stålnacke, P.; Grimvall, A.; Wittgren, H.B. Riverine input of nutrients to the Gulf of Riga-Temporal and spatial variation. J. Mar. Syst. 1999, 23, 11-25. [CrossRef]

55. Stankunavicius, G.; Valiuskevicius, G.; Rimkus, E.; Bukantis, A.; Gulbinas, Z. Meteorological features behind spring runoff formation in the Nemunas River. Boreal Environ. Res. 2007, 12, 643-651.

56. Fulweiler, R.W.; Nixon, S.W. Terrestrial vegetation and the seasonal cycle of dissolved silica in a southern New England coastal river. Biogeochemistry 2005, 74, 115-130. [CrossRef]

57. Korth, F.; Fry, B.; Liskow, I.; Voss, M. Nitrogen turnover during the spring outflows of the nitrate-rich Curonian and Szczecin lagoons using dual nitrate isotopes. Mar. Chem. 2013, 154, 1-11. [CrossRef]

58. Todd, R.W.; Cole, N.A.; Harper, L.A.; Flesch, T.K. Flux-gradient estimates of ammonia emissions from beef cattle feed yard pens. Am. Soc. Agric. Biol. Eng. 2007. [CrossRef]

59. Stålnacke, P. Nutrient Loads to the Baltic Sea 1996. Ph.D. Thesis, The Linköpings University, Linköping, Swedish, September 1996.

60. Ramoska, E.; Bastiene, N.; Saulys, V. Evaluation of controlled drainage efficiency in Lithuania. Irrig. Drain. 2011, 60, 196-206. [CrossRef]

61. Pilkaitytè, R.; Razinkovas, A. Factors controlling phytoplankton blooms in a temperate estuary: Nutrient limitation and physical forcing. Hydrobiologia 2006, 555, 41-48. [CrossRef]

62. Conley, D.J. Riverine contribution of biogenic silica to the oceanic silica budget. Limnol. Oceanogr. 1997, 42, 774-777. [CrossRef]

63. Justić, D.; Rabalais, N.N.; Turner, R.E.; Dortch, Q. Changes in nutrient structure of river-dominated coastal waters: Stoichiometric nutrient balance and its consequences. Estuar. Coast Shelf Sci. 1995, 40, 339-356. [CrossRef]

64. Kronvang, B.; Jeppesen, E.; Conley, D.J.; Søndergaard, M.; Larsen, S.E.; Ovesen, N.B.; Carstensen, J. Nutrient pressures and ecological responses to nutrient loading reductions in Danish streams, lakes and coastal waters. J. Hydrol. 2005, 304, 274-288. [CrossRef]

65. Paerl, H.W. Controlling eutrophication along the freshwater-marine continuum: Dual nutrient (N and $\mathrm{P})$ reductions are essential. Estuar. Coast 2009, 32, 593-601. [CrossRef]

66. Nawrocka, L.; Kobos, J. The trophic state of Vistula lagoon: An assessment based on biotic and abiotic pameters according to Water Framework Directive. Oceanologia 2011, 53, 881-894. [CrossRef]

67. Bresciani, M.; Giardino, C.; Stroppiana, D.; Pilkaityt, R.; Zilius, M.; Bartoli, M.; Razinkovas, A. Retrospective analysis of spatial and temporal variability of chlorophyll-a in the Curonian Lagoon. J. Coast Conserv. 2012, 16, 511-519. [CrossRef]

68. Zilius, M.; Vybernaite-Lubiene, I.; Vaiciute, D.; Petkuviene, J.; Zemlys, P.; Liskow, I.; Voss, M.; Bartoli, M.; Bukaveckas, P.A. The influence of cyanobacteria blooms on the attenuation of nitrogen throughputs in a Baltic coastal lagoon. Biogeochemistry 2018, submitted.

69. Humborg, C.; Smedberg, E.; Rodriguez Medina, M.; Mörth, C.M. Changes in dissolved silicate loads to the Baltic Sea-The effects of lakes and reservoirs. J. Mar. Syst. 2008, 73, 223-235. [CrossRef]

70. Conley, D.J.; Humborg, C.; Smedberg, E.; Rahm, L.; Papush, L.; Danielsson, Å.; Clarke, A.; Pastuszak, M.; Aigars, J.; Ciuffa, D.; Mörth, C.M. Past, present and future state of the biogeochemical Si cycle in the Baltic Sea. J. Mar. Syst. 2008, 73, 338-346. [CrossRef]

71. Helsinki Commission. Baltic Sea Action Plan. Presented at HELCOM Ministerial Meeting, Krakow, Poland, 15 November 2007.

72. Andersen, H.E.; Blicher-Mathiesen, G.; Thodsen, H.; Andersen, P.M.; Larsen, S.E.; Stålnacke, P.; Humborg, C.; Mörth, C.M.; Smedberg, E. Identifying hot spots of agricultural nitrogen loss within the Baltic Sea drainage basin. Water Air Soil Poll. 2016, 227, 38. [CrossRef]

73. Hong, B.; Swaney, D.P.; McCrackin, M.; Svanbäck, A.; Humborg, C.; Gustafsson, B.; Yershova, A.; Pakhomau, A. Advances in NANI and NAPI accounting for the Baltic drainage basin: Spatial and temporal trends and relationships to watershed TN and TP fluxes. Biogeochemistry 2017, 133, 245-261. [CrossRef]

74. Grelowski, A.; Pastuszak, M.; Sitek, S.; Witek, Z. Budget calculations of nitrogen, phosphorus and BOD 5 passing through the Oder estuary. J. Mar. Syst. 2000, 5, 221-237. [CrossRef] 
75. Petkuviene, J.; Zilius, M.; Lubiene, I.; Ruginis, T.; Giordani, G.; Razinkovas-Baziukas, A.; Bartoli, M. Phosphorus Cycling in a Freshwater Estuary Impacted by Cyanobacterial Blooms. Estuar. Coast 2016, 39, 1386-1402. [CrossRef]

76. Andersen, H.E.; Blicher-Mathiesen, G.; Bechmann, M.; Povilaitis, A.; Iital, A.; Lagzdins, A.; Kyllmar, K. Mitigating diffuse nitrogen losses in the Nordic-Baltic countries. Agric. Ecosyst. Environ. 2014, 195, 53-60. [CrossRef]

(c) (C) 2018 by the authors. Licensee MDPI, Basel, Switzerland. This article is an open access article distributed under the terms and conditions of the Creative Commons Attribution (CC BY) license (http://creativecommons.org/licenses/by/4.0/). 